\title{
Clostridium difficile infection: main features and occurrence in domestic species in Brazil
}

\author{
Infecção por Clostridium difficile: principais características e ocorrência em animais domésticos \\ no Brasil
}

\section{Rodrigo Otávio Silveira Silva ${ }^{\mathrm{I}}$ Roberto Maurício de Carvalho Guedes ${ }^{\mathrm{I}}$ Francisco Carlos Faria Lobato $^{\mathrm{I}}$}

\section{- REVIEW -}

\section{ABSTRACT}

Clostridium difficile is an emerging enteropathogen of humans and domestic animals. The bacterium was recently confirmed to be present in foals and dogs in Brazil, with some recent studies suggesting that $\boldsymbol{C}$. difficile is one of the most important causes of piglet diarrhea in the country. Moreover, some reports also suggest the transmission of this microorganism between animals and humans, raising the possibility that $\boldsymbol{C}$. difficile is a zoonotic disease. Therefore, the aim of the present review is to describe the main features of $\boldsymbol{C}$. difficile infection in domestic animals and outline the occurrence of the disease in horses, dogs and pigs in Brazil.

Key words: enteritis, zoonosis, clostridiosis, nosocomial, piglets, foals, dogs.

\section{RESUMO}

Clostridium difficile é considerado um enteropatógeno emergente que acomete humanos e animais domésticos. A presença da doença em equinos e cães já foi relatada no Brasil e trabalhos sugerem que atualmente $\boldsymbol{C}$. difficile seja um dos principais causadores de diarreia neonatal em suínos no país. Além disso, relatos recentes sugerem a transmissão do agente entre o homem e animais, gerando a hipótese de $\boldsymbol{C}$. difficile ser um agente zoonótico. Com isso, o presente trabalho tem como objetivo revisar as principais características da doença, além de fornecer dados recentes sobre a ocorrência no Brasil da infecção por C. difficile nas principais espécies de animais domésticos.

Palavras-chave: enterite, zoonose, clostridiose, nosocomial, leitões, potros, cães.

\section{INTRODUCTION}

Clostridium difficile is an anaerobic grampositive bacterium that is considered an emerging pathogen and currently responsible for the majority of the nosocomial diarrhea and pseudomembranous colitis cases in humans. $\boldsymbol{C}$. difficile infection is common in pigs and horses but also occurs in dogs, calves and laboratory animals, such as guinea pigs, rabbits and hamsters (KEEL \& SONGER, 2006). C. difficile has emerged as an important enteric pathogen in piglets and now is considered the primary cause of uncontrolled neonatal diarrhea in the U. S. and Europe (SONGER, 2010). This bacterium was not reported in domestic animals in Brazil until 2011. Since then, studies have confirmed $\boldsymbol{C}$. difficile-associated infections in piglets, foals and dogs (SILVA et al., 2011; PREIS et al., 2012; SILVA et al., 2013). Despite the growing importance of $\boldsymbol{C}$. difficile-associated infections, the basic aspects of the disease, such as clinical presentation, diagnostic methods and methods for preventing and controlling the disease, are largely unknown. Thus, the present article aims to review the primary features of the disease and provide recent data on the occurrence of $\boldsymbol{C}$. difficile infection in domestic animal species in Brazil.

IEscola de Veterinária, Universidade Federal de Minas Gerais (UFMG), 30123-970, Belo Horizonte, MG, Brasil. E-mail: lobato.francisco@yahoo.com.br.*Autor para correspondência. 
Background and Pathogenesis

C. difficile was first isolated from the feces of newborns by HALL and O'TOLLE in 1935. Because this microorganism was not yet recognized as a pathogen, few studies were published before the 1970s. In this decade, concomitant with the extensively use of clindamycin, reports of diarrhea and pseudomembranous colitis started to emerge (LYERLY et al., 1988). Few years later, $\boldsymbol{C}$. difficile was confirmed as the principle causative agent of diarrhea associated with prolonged antibiotic therapy in humans. Nowadays, the impact of the disease is still not entirely known, but it has been estimated that approximately three million cases occur annually in the United States alone (OLDFIELD, 2004). Unfortunately, studies about C. difficile in humans in Brazil are rare.

C. difficile was first isolated from piglets and horses in the 1980s (JONES and HUNTER, 1983; EHRLICH et al., 1984), but it was not until the mid1990 s that this microorganism gained greater appreciation as a cause of diarrhea in these two species (SONGER, 2010). Several recent studies have attempted to standardize diagnostic methods and evaluate the hypothesis that $\boldsymbol{C}$. difficile is a zoonotic agent, while other studies have researched immunoprophylactic treatments that can prevent the diarrhea caused by this emerging microorganism (SONGER et al., 2007).

The pathogenesis of $\boldsymbol{C}$. difficile-associated diarrhea is still largely unknown for the majority of animals. It is believed that infection is initiated by ingesting spores, which are primarily transmitted by infected animals or healthy carriers. In general, the intestinal microbiota prevents the agent from colonizing, as infection requires the absence of microbiota that inhibit colonization. Thus, $\boldsymbol{C}$. difficile commonly colonizes the intestine after the antibiotic-mediated depletion of intestinal microorganisms or prior to the complete establishment of the microbiota, which occurs in piglets shortly after birth (BAVERUD, 2004). It is also possible for strains already inhabiting healthy horses and dogs to experience exacerbated growth after the impairment of the intestinal microbiota (HOPMAN et al., 2011).

Once in the intestines, $\boldsymbol{C}$. difficile can produce two toxins: toxin A, an enterotoxin, and toxin B, a cytotoxin. Intestinal lesions appear to be initiated by toxin $\mathrm{A}$, the receptors for which are present on the basal lamina of intestinal epithelial cells. The cell junctions are destroyed, allowing toxin B, whose receptors are believed to be located on the basolateral region of the epithelium, to enhance the lesion. After internalization by endocytosis, both of the toxins condense actin, causing disruption of the cytoskeleton, cell rounding and ultimately apoptosis. Following injury to the intestinal epithelium, the toxins can disseminate systemically and act on other organs. In addition, the destruction of cell junctions causes an intense intestinal leukocyte migration that result in the formation of a pseudomembrane, which is a characteristic of the disease in humans (LYERLY et al., 1988).

A third toxin, binary toxin, has caught the attention of both researchers and clinicians but, despite many discussions, the real significance of this additional virulence factor is still unknown. Human studies have reported greater disease severity in patients infected with binary toxin-producing strains (RUPNIK et al., 2005). Recent studies showed that the binary toxin may act synergistically with toxins A and B, increasing the depolymerization of the cytoskeleton through a complementary mechanism, and it also appears to form protrusions in target cells and cause the consequent expulsion of material from the cytosol. This material forms a dense network on the cell surface that facilitates the adhesion and multiplication of $\boldsymbol{C}$. difficile in the intestine (SCHWAN et al., 2009).

The disease in piglets

C. difficile infections in pigs occur almost exclusively in piglets younger than seven days old. Unlike humans, the development of the disease in this species is not necessarily correlated with the use of antibiotics (SONGER \& UZAL, 2005). C. difficile is widespread in the environment and is potentially present in the feces of sows; thus, the intestinal colonization of piglets occurs shortly after birth (HOPMAN et al., 2011). C. difficile infections are clinically characterized by weak body growth and mesocolon edema. Other signs, such as hydrothorax, respiratory distress, scrotal and facial edema and even sudden death, can also occur (SONGER \& UZAL, 2005). Approximately $30 \%$ of the animals on affected farms are positive for the presence of toxins $\mathrm{A} / \mathrm{B}$, with the prevalence reaching $100 \%$ in some cases (SONGER et al., 2004). It is worth noting that only some of the infected animals have diarrhea, which may vary in consistency from pasty to watery. The simple absence of diarrheal content in the colon does not rule out the possibility of infection, as the disease is commonly subclinical in pigs (YAEGER et al., 2007).

Mesocolon colitis and edema (Figure 1C) are the macroscopic changes that best correlate with the presence of $\boldsymbol{C}$. difficile infections in piglets, especially when the edema is severe. Notably, however, it is common on affected farms to find several seemingly healthy piglets that test positive for the A/B toxins and exhibit histopathological intestinal lesions. Thus, 


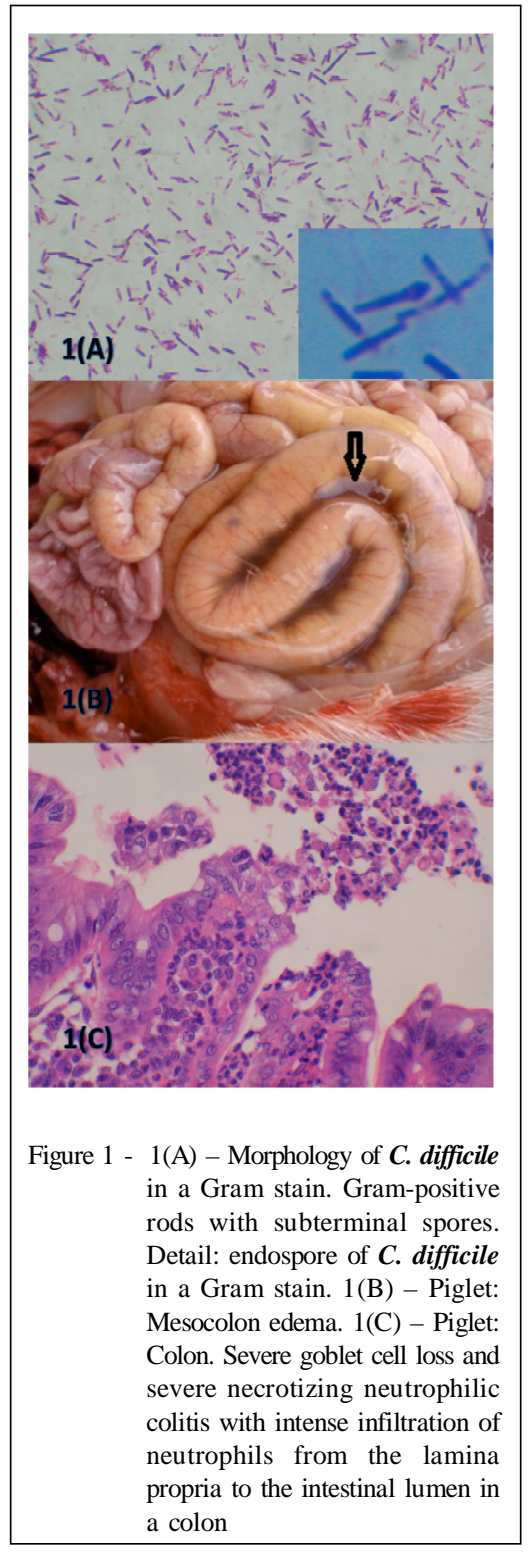

microscopic evaluations are extremely valuable in confirming a diagnosis, as several clinical signs are often observed in positive animals, including suppuration in the lamina propria of the colon, edema, the infiltration of neutrophils into the serosa and mesentery, a marked reduction in the number of goblet cells and the presence of stereotypical lesions known as "volcano lesions" (Figure 1D) (YAEGER et al., 2007).

In Brazil, two different surveys conducted in Rio Grande do Sul and Minas Gerais found that approximately $16 \%$ of the animals were positive for the A/B toxins (LIPPKE et al., 2011; SILVA et al., 2011). Interestingly, $53 \%$ of the farms sampled in the latter study had at least one positive animal, suggesting widespread dissemination of the disease. CRUZJUNIOR et al. (2010) evaluated the main causative agents (rotavirus, enterotoxigenic $\boldsymbol{E}$. coli, Isospora suis, $\boldsymbol{C}$. perfringens and $\boldsymbol{C}$. difficile) of neonatal diarrhea in pigs in Minas Gerais. The A/B toxins and/or histological lesions characteristic of $\boldsymbol{C}$. difficile were present in $50 \%$ of the animals examined. Thus, similar to reports from the U. S. and Europe, these results suggest that infection by this agent is one of the most important causes of neonatal diarrhea in pigs in Brazil.

The disease in horses and foals

C. difficile is responsible for colitis in adult horses, mostly nosocomial, and for diarrhea ranging from a mild self-limiting form to a per-acute and fatal disease in foals (MEDINA-TORRES et al., 2010). In foals, as in humans, infection rarely occurs spontaneously and is usually associated with an imbalance in the gastrointestinal microbiota, especially when the imbalance occurs after the use of antibiotics (WEESE et al., 2000). The antimicrobials commonly associated with the development of $\boldsymbol{C}$. difficileassociated infections in horses include erythromycin, ceftiofur, norfloxacin, florfenicol, lincomycin and general beta-lactams (BÅVERUD, 2004). Interestingly, the use of multiple antibiotics has been associated with an increased risk of developing $\boldsymbol{C}$. difficile infection in foals (BÅVERUD, 2002). Infected animals present clinically with diarrhea that is often profuse, dehydration, depression and a significant amount of gas in their large intestines (BÅVERUD, 2004). Recently, UZAL et al (2012) reported a possible association between $\boldsymbol{C}$. difficile and $\boldsymbol{C}$. perfringens type $\mathrm{C}$ as a cause of acute diarrhea in foals, but further studies are needed to confirm this hypothesis.

There are currently only two diagnostic descriptions of $\boldsymbol{C}$. difficile infections in foals in Brazil (PREIS et al., 2012; SILVA et al., 2012), both at Minas Gerais. The prevalence of the disease in adult horses and foals remains unclear in Brazil because of a lack of epidemiological surveys. SILVA et al. (2012) reported the occurrence of diarrhea in three five-month-old animals two days after the administration of penicillin to treat suspected pneumonia. PREIS et al. (2012) have already described a case of $\boldsymbol{C}$. difficile enteritis that was associated with candidiasis and prolonged antibiotic therapy in a 12-day-old animal. In both reports, the infection was initially suspected to be salmonellosis. Only in the first report was an ante mortem laboratory diagnosis performed, allowing the antibiotic therapy to be adjusted to focus on the $\boldsymbol{C}$. difficile infection and recovery of the animals. PREIS 
et al. (2012) explained that the absence of a laboratory diagnosis might have further aggravated the disease because the antibiotics were chosen based on the suspected salmonellosis and ultimately lead to the animal's death. In both cases, the A/B toxins were detected by the cytotoxicity assay and also toxigenic strains of $\boldsymbol{C}$. difficile were isolated. These studies confirmed the occurrence of the disease in horses in Brazil and demonstrate the need for a differential diagnosis for diarrhea in foals, especially when the clinical signs of diarrhea begin a few days following antibiotic therapy or in cases where some compounds, such as ceftiofur, norfloxacin or florfenicol, do not result in a significant clinical improvement.

In adult horses, $\boldsymbol{C}$. difficile has been reported as a nosocomial causative agent of acute diarrhea or cramping during hospitalization, which occurs after antibiotic therapy for another disease (BÅVERUD et al., 2004). However, to date, there are no reports of $\boldsymbol{C}$. difficile-associated infections in adult horses in Brazil.

\section{The disease in dogs}

The importance of $\boldsymbol{C}$. difficile-associated diarrhea in dogs is still not fully known. It was initially believed that this agent was only responsible for rare cases of chronic recurrent diarrhea. However, studies have demonstrated that the risk of colonization increases significantly with hospitalization and that infection with a toxigenic strain of $\boldsymbol{C}$. difficile during hospitalization is correlated with the development of diarrhea (STRUBLE et al., 1994). The administration of antibiotics and immunosuppressive drugs during hospitalization promotes the intestinal colonization of dogs, suggesting that the use of these drugs in conjunction with hospitalization is the main risk factor for the development of $\boldsymbol{C}$. difficile-associated diarrhea. Since the publication of these studies, this agent has been recognized as a nosocomial pathogen in dogs, as it is in adult humans and horses (CLOOTEN et al., 2008).

Only one study on $\boldsymbol{C}$. difficile has confirmed the occurrence of infection in dogs in Brazil (SILVA et al., 2013). This study evaluated isolates to determine whether the toxins $\mathrm{A} / \mathrm{B}$ were present in diarrheic dogs at a veterinary hospital and apparently healthy animals outside a hospital setting. Similar to the results reported in other studies, SILVA et al. (2013) showed a significant association between the occurrence of diarrhea and the presence of toxins $\mathrm{A} / \mathrm{B}$, suggesting the involvement of $\boldsymbol{C}$. difficile in canine diarrhea (STRUBLE et al., 1994; CLOOTEN et al., 2008).

Despite recent advances, additional research is needed to clarify some of the questions regarding $\boldsymbol{C}$. difficile infection in dogs. These questions include determining the role of $\boldsymbol{C}$. difficile in diarrhea occurring in non-hospitalized animals that did not previously receive antibiotic therapy. Although there are several reports on this topic, there is still no convincing evidence, leaving this question unresolved.

\section{Clostridium difficile as a zoonotic agent}

With the development and application of molecular biology techniques, studies examining $\boldsymbol{C}$. difficile strains from various sources have become more common. Ribotyping is currently the most commonly used technique and allows a library of more than 160 patterns (ribotypes) to be generated from $\boldsymbol{C}$. difficile strains isolated from animals, humans and the environment (SONGER et al., 2010). Recent studies have used this ribotyping technique to show that the C. difficile strains isolated from meat products are very similar to those strains isolated from humans with pseudomembranous colitis, suggesting the possibility of transmission through foods of animal origin (SONGER et al., 2009). Consequently, some studies were conducted to evaluate the similarity of the strains isolated from humans and domestic animals. These studies noted that many of the ribotypes isolated from cattle, pigs and dogs were the same ribotypes found in humans with pseudomembranous colitis (JHUNG et al., 2008). Moreover, a recent study reported that occupational exposure to pigs significantly increases the likelihood of humans being colonized by $\boldsymbol{C}$. difficile . Furthermore, the same study demonstrated that the strains isolated from animals and their handlers had the same ribotype, suggesting transmission between species (NORMAN et al., 2011). Another fact that has attracted attention is the large increase in the isolation of one specific ribotype, known as 078, from humans living in the United States and England. This strain is commonly isolated from calves and represents $83 \%$ of the isolates obtained from pigs in the United States (KEELet al., 2007).

These results reinforce the hypothesis that C. difficile is transmitted between animals and humans. In parallel with this hypothesis, recent events indicate changes in the epidemiology of $\boldsymbol{C}$. difficile infections, including the occurrence of disease in patients with immunodeficiency, transplanted patients and otherwise healthy humans and those without prior exposure to a hospital environment (SAMIE et al., 2008; COLLINI et al., 2012). More studies are needed to confirm the hypothesis that $\boldsymbol{C}$. difficile is a zoonotic agent, so that, if this suspicion is confirmed, preventing the disease (and even preventing colonization) in domestic animals can be made a priority (SONGER, 2010).

Ciência Rural, v.43, n.1, jan, 2013. 
Unfortunately, $\boldsymbol{C}$. difficile ribotyping studies in Brazil are scarce and restricted to human isolates (BALASSIANO et al., 2009). To date, there are no Brazilian studies evaluating the ribotypes of $\boldsymbol{C}$. difficile isolates from domestic animals, which impedes the evaluation of strains isolated from humans and animals.

Diagnostics

Detection of the toxins

Detecting toxins A/B by visualizing their cytopathic effects in cell culture (cell cytotoxicity assay - CTA) is considered the gold standard for diagnosing C. difficile infections. The CTA consists of inoculating filtered feces into a cell culture and observing its cytopathic effect. The cytotoxic effect is primarily mediated by toxin $\mathrm{B}$, which is 1000 times more cytotoxic than toxin A. Readings are taken 24-48 hours later and confirmed by seroneutralization of the cytopathic effect with antibodies against the $\mathrm{A} / \mathrm{B}$ toxins of $\boldsymbol{C}$. difficile or C. sordellii (DELMEÉ, 2001).

One of the primary advantages of the CTA is its high sensitivity and specificity. Conversely, the assay requires at least two days and can only evaluate a few samples at one time, in contrast to other techniques such as commercial enzyme linked immunosorbent assay (ELISA) or immunochromatography (ICG) kits. Another disadvantage is the maintenance of cell lines, which is also time consuming, relatively expensive and requires trained personnel (POST et al., 2002).

The commercial kits that detect toxins A and $\mathrm{B}$ are easy to use and provide results quickly, taking only a few hours. Unfortunately, all of the commercially available kits are imported, increasing the costs associated with a diagnosis. In addition, all of these kits are standardized to detect toxins A/B from human feces, and the sensitivity and specificity are highly variable between kits and animal species. Notably, some kits are only standardized for detecting toxin A. Studying both toxins is essential because some $\boldsymbol{C}$. difficile-associated infections, including major outbreaks in humans, have been caused by variant strains that produce only toxin B (KUIJPER et al., 2001).

Studies evaluating the effectiveness of kits at detecting the $\mathrm{A} / \mathrm{B}$ toxins in pig specimens suggest that such products are less effective for this species (KEESSENet al., 2011; SONGER and ANDERSON, 2006). In general, the sensitivity or specificity of the kits tested thus far is unacceptably low. However, one exception has been reported by POST et al. (2002), who evaluated a kit exhibiting $91 \%$ sensitivity and $86 \%$ specificity for swine feces. CHOUICHA \& MARKS (2006) evaluated five commercial ELISA kits for their effectiveness on dog feces, concluding that all were inadequate because of low sensitivity (the sensitivities ranged from $7 \%$ to $33 \%$ ). Thus, the use of commercial kits for pigs or dogs does not seem to yield an adequate individual diagnosis. It has been speculated that, for both dogs and pigs, the sensitivity and specificity of ELISA kits are compromised by the presence of inhibitors and fecal proteases, which decrease the binding specificity and/or degrade the toxins in the feces, respectively (CHOUICHA \& MARKS, 2006). To date only one kit has been evaluated on horses and with $84 \%$ sensitivity and $96 \%$ specificity its performance was considered adequate (MEDINATORRES et al., 2010).

No studies have evaluated the commercial kits from Brazil using clinical samples from horses, pigs or dogs, complicating the diagnosis of $\boldsymbol{C}$. difficile infections in domestic species in the country. Given that the significant prevalence of the disease in pigs has been confirmed and that the infection has also been confirmed in dogs and horses, evaluating these kits and standardizing the diagnosis of $\boldsymbol{C}$. difficileassociated infections in each domestic species will be crucial in achieving a more complete epidemiological assessment and implementing control measures and more effective treatments.

\section{Isolation and PCR}

The most commonly used agar for isolating C. difficile from feces is the CCFA agar (cycloserine cefoxitin fructose agar) (DELMEÉ, 2001). Several modifications of CCFA agar have been proposed over the years. Of these modifications, the addition of taurocholate to CCFA (TCCFA) has proven to be effective at improving the recovery of $\boldsymbol{C}$. difficile spores (RAMIREZ et al., 2010). Another approach commonly used to improve the isolation of $\boldsymbol{C}$. difficile is alcohol shock prior to plating. Alcohol shock increases the sensitivity of the isolation by eliminating the vegetative forms and other bacteria present in the feces while allowing the $\boldsymbol{C}$. difficile spores to persist (BORRIELLO \& HONOUR, 1981). According to SONGER \& UZAL (2005), some strains cannot grow because they are sensitive to one or both of the antibiotics used in the selective medium.

C. difficile colonies are easily recognizable by their morphology, which includes an aspect known as "ground glass", and gram-positive rods with subterminal spores can be observed with a Gram stain (Figure 1A and 1B). However, in addition to a presumptive diagnosis based on colony and Gram stain morphology, additional tests are required to confirm its identity. Currently, the polymerase chain reaction (PCR) is the most widely used technique for identity confirmation. In addition to confirming identity, most 
techniques also detect the genes encoding toxin $\mathrm{A}$ $(t c d A)$, toxin $\mathrm{B}(t c d B)$ and additional virulence factors such as the binary toxin ( $c d t B$ ) (SILVA et al., 2011).

Because $\boldsymbol{C}$. difficile can be a normal inhabitant of the intestinal microbiota, simply isolating the microorganism does not confirm the disease in humans or domestic animals. Thus, isolation is only used in epidemiological investigations and to assess the antibiotic sensitivity of the microorganism. However, recent studies have shown that evaluating the in vitro production of toxins $\mathrm{A} / \mathrm{B}$ by the strain (a technique known as toxigenic culture, or TC) after isolation yields a relatively high correlation to disease occurrence (KEESSEN et al., 2011). Thus, many studies have supported TC as the "gold standard" for diagnosis in some species (KEESSEN et al., 2011). In general, the technique has good sensitivity, but variable specificity. By all indications, this test would be an interesting test for screening, but, like the CTA, TC is labor intensive and requires a relatively long time (at least 72 hours) to obtain results.

Other diagnostic options still unavailable in Brazil include the commercial real-time PCR (rPCR) kits for detecting the $t c d B$ gene from DNA extracted directly from the feces. The rPCR technique has not been evaluated in horse samples, but reports suggest that rPCR has a high sensitivity for human and pig samples (SCHMIDT et al., 2009; KEESEN et al., 2011). Conversely, specificity has been widely discussed because of the possibility of asymptomatic carriers, which would generate false positives. The current proposal is to use rPCR as a primary screening method and CTA, TC or commercial ELISA kits to confirm positive results (KEESSEN et al., 2011).

In Brazil, $C$. difficile infections are currently diagnosed by detecting the A/B toxins with a CTA or ELISAs. In addition, a histopathological evaluation has proven to be an essential auxiliary tool to confirm the presence of the disease in pigs or, in cases of death, horses. For pigs, obtaining multiple samples from a suspected farm appears to significantly increase the sensitivity of ELISA kits that have a low sensitivity but high specificity (KEESSEN et al., 2011). In any case, studies evaluating the commercially available Brazilian ELISA kits are essential in determining which kits are suitable for diagnostics and which are the most suitable for each domestic species.

Treatment and control of $\boldsymbol{C}$. difficile infections

Because $\boldsymbol{C}$. difficile vaccines are not currently available, the control of $\boldsymbol{C}$. difficile infections in domestic animals is based on general management measures. C. difficile spores can remain viable for long periods of time and are resistant to most disinfectants, thus permitting $\boldsymbol{C}$. difficile to become a major environmental contaminant, especially in hospitals (BUGGY et al., 1983). Reducing environmental contamination and dissemination is essential, and two strategies of paramount importance are the correct use of products containing active chlorine and proper hand hygiene. Isolating suspect horses and dogs is also essential. It is also important to note that using alcohol gels on the hands to eliminate the spores of this microorganism is ineffective (MACLEOD-GLOVER \& SADOWSKI, 2010).

In humans, a toxoid vaccine aimed at preventing $\boldsymbol{C}$. difficile-associated diarrhea is in the final phase of testing and has shown great potential (GREENBERG et al., 2012). Unfortunately, the same cannot be said for domestic animals, as few studies have evaluated the immunity of horses and pigs against C. difficile and its toxins. Another alternative that may be used for prevention and treatment in the future is the administration of non-toxigenic $\boldsymbol{C}$. difficile strains. Experiments have demonstrated that humans and animals that have been previously colonized by these strains have a lower chance of being infected by a toxigenic strain and developing diarrhea (SILVA et al., 2011). Since the publication of these reports, other studies have evaluated the potential of administering non-toxigenic $\boldsymbol{C}$. difficile strains orally, with encouraging results reported in humans and pigs (SONGER et al., 2010).

Until now, there is no work evaluating the susceptibility of Brazilians' isolates from animals to commonly used antimicrobials. Studies examining the antimicrobial sensitivity of $\boldsymbol{C}$. difficile strains isolated from pigs in EUA suggest that tiamulin, virginiamycin and tylosin, which are included in animal feed, may be useful in prophylaxis or therapy (SONGER \& ANDERSON, 2006). In horses and dogs, it is recommended that for diarrheic animals, in addition to basic support therapy, the infection-causing antibiotic be immediately replaced by metronidazole, the firstchoice drug, or vancomycin (BÅVERUD, 2004).

\section{REFERENCES}

BALASSIANO, I.T. et al. Characterization of Clostridium difficile strains isolated from immunosuppressed inpatients in a hospital in Rio de Janeiro, Brazil. Anaerobe, v.15, n.3, p.6164, 2009. Avaliable from: <http://www.ncbi.nlm.nih.gov/ pubmed/19154793>. Acessed: nov 2, 2012. doi: 10.1016/ j.anaerobe.2008.12.007.

BÅVERUD, V. Clostridium difficile infections in animals with special reference to the horse. A review. Veterinary Quartely, v.24, n.4, p.203-219, 2002. Avaliable from: <http:// www.ncbi.nlm.nih.gov/pubmed/12540137>. Acessed: nov 2, 2012. 
BÅVERUD, V. Clostridium difficile diarrhea: infection control in horses. Veterinary Clinics of North American Equine Practice, v.20, n.3, p.615-630, 2004. Avaliable from: <http:// www.ncbi.nlm.nih.gov/pubmed/15519822>. Acessed: nov 2, 2012.

BORRIELLO, S.P.; HONOUR, P. Simplified procedure for the routine isolation of Clostridium difficile from faeces. Journal of Clinical Pathology, v.34, n.10, p.1124-7, 1981. Avaliable from: <http://www.ncbi.nlm.nih.gov/pubmed/7031097>. Acessed: nov 2, 2012.

BUGGY, B.P. et al. Comparison of methods for recovery of Clostridium difficile from an environmental surface. Journal of Clinical Microbiology, v.18, n.2, p.348-52 1983. Avaliable from: <http://www.ncbi.nlm.nih.gov/pubmed/6619285>. Acessed: nov 2, 2012.

CHOUICHA, N.; MARKS, S.L. Evaluation of five enzyme immunoassays compared with the cytotoxicity assay for diagnosis of Clostridium difficile-associated diarrhea in dogs. Journal of Veterinary Diagnostic Investigation, v.18, n.182-188, 2006. Avaliable from: <http://www.ncbi.nlm.nih.gov/pubmed/ 16617699>. Acessed: nov 2, 2012.

ClOOTEN, J. et al. Prevalence and risk factors for Clostridium difficile colonization in dogs and cats hospitalized in an intensive care unit. Veterinary Microbiology, v.129, p.209-214, 2008. Avaliable from: <http://www.ncbi.nlm.nih.gov/pubmed/ 18164560>. Acessed: nov 2, 2012. doi: 10.1016/ j.vetmic.2007.11.013.

COLLINI, P.J. et al. Clostridium difficile infection in HIVseropositive individuals and transplant recipients. Journal of Infection, v.64, n.2, p.131-147, 2012. Avaliable from: <http:/ /www.ncbi.nlm.nih.gov/pubmed/22178989>. Acessed: nov 2, 2012. doi: 10.1016/j.jinf.2011.12.003.

CRUZ JUNIOR, E.C.C. Diagnóstico de enteropatógenos em leitões até sete dias de idade. 2010. 55f. Dissertação (Mestrado em Ciência Animal) - Universidade Federal de Minas Gerais, MG.

DELMÉE, M. Laboratory diagnosis of Clostridium difficile disease. Clinical Microbiology and Infection, v.7, n.8, p.411416, 2001. Avaliable from: <http://www.ncbi.nlm.nih.gov/pubmed/ 11591203>. Acessed: nov 2, 2012.

EHRLICH, M. et al. Acute diarrhea in horses of the Potomac River area: examination for clostridial toxins. Journal of the American Veterinary Medical Association, v.185, n.4, p.433435, 1984. Avaliable from: <http://www.ncbi.nlm.nih.gov/pubmed/ 6469842>. Acessed: nov 2, 2012.

GREENBERG, R.N. et al. Phase I dose finding studies of an adjuvanted Clostridium difficile toxoid vaccine. Vaccine, v.30, n.13, p.2245-9, 2012. Avaliable from: <http:// www.ncbi.nlm.nih.gov/pubmed/22306375>. Acessed: nov 2, 2012. doi: 10.1016/j.vaccine.2012.01.065.

HALL, I.C.; O'TOOLE, E. Intestinal flora in new-born infants. American Journal of Diseases of Children, v.49, p.390402,1935 .

HOPMAN, N.E. et al. Acquisition of Clostridium difficile by piglets. Veterinary Microbiology, v.149, n.1, p.186-192, 2011. Avaliable from: <http://www.ncbi.nlm.nih.gov/pubmed/ 21111541>. Acessed: nov 2, 2012.
JHUNG, M.A. et al. Toxinotype V Clostridium difficile in humans and food animals. Emerging Infectious Disease, v.14, n.7, p.1039-1045, 2008. Avaliable from: <http://www.ncbi.nlm.nih.gov/ pubmed/18598622>. Acessed: nov 2, 2012.

JONES, M.A., HUNTER, D. Isolation of Clostridium difficile from pigs. Veterinary Record, v.112, n.11: p.253, 1983. Avaliable from: <http://www.ncbi.nlm.nih.gov/pubmed/ 6845597>. Acessed: nov 2, 2012.

KEEL, M.K.; SONGER, J.G. The comparative pathology of Clostridium difficile-associated disease. Veterinary Pathology, v.43, n.3,p.225-40, 2006. Avaliable from: <http:// www.ncbi.nlm.nih.gov/pubmed/16672570>. Acessed: nov 2, 2012.

KEEL, M.K. et al. Prevalence of PCR ribotypes among Clostridium difficile isolates from pigs, calves, and other species. Journal of Clinical Microbiology, v.45, n.6, p.1963-1964, 2007. Avaliable from: <http://www.ncbi.nlm.nih.gov/pubmed/ 1933037>. Acessed: nov 2, 2012. doi: 10.1128/?JCM.00224-07.

KEESSEN, E.C. et al. Evaluation of four different diagnostic tests to detect Clostridium difficile in piglets. Journal of Clinical Microbiology, v.49, n.5, p.1816-1821, 2011. Avaliable from: <http://www.ncbi.nlm.nih.gov/pubmed/21411571>. Acessed: nov 2, 2012. doi: 10.1128/JCM.00242-11.

KUIJPER, E.J. et al. Nosocomial outbreak of Clostridium difficile-associated diarrhea due to a clindamycin-resistant enterotoxin A-negative strain. European Journal of Clinical Microbiology \& Infectious Diseases, v.20, n.8, p.528-534, 2001. Avaliable from: <http://www.ncbi.nlm.nih.gov/pubmed/ 11681431>. Acessed: nov 2, 2012.

LIPPKE, R.T. et al. Matched case-control study evaluating the frequency of the main agents associated with neonatal diarrhea in piglets. Pesquisa Veterinária Brasileira, v.31, n.6, p.505$510,2011$.

LYERLY, D.M. et al. Clostridium difficile: its disease and toxins. Clinical Microbiology Reviews. v.1, n.1, p.1-18, 1988. Avaliable from: <http://www.ncbi.nlm.nih.gov/pubmed/ 3144429>. Acessed: nov 2, 2012.

MACLEOD-GLOVER, N.; SADOWSKI, C. Efficacy of cleaning products for $\boldsymbol{C}$. difficile: environmental strategies to reduce the spread of Clostridium difficile-associated diarrhea in geriatric rehabilitation. Canadian Family Physician, v.56, n.5, p.417423, 2010. Avaliable from: <http://www.ncbi.nlm.nih.gov/pubmed/ 20463269>. Acessed: nov 2, 2012.

MEDINA-TORRES, C.E. et al. Prevalence of Clostridium difficile in horses. Veterinary Microbiology, v.152, p.212215, 2010. Avaliable from: <http://www.ncbi.nlm.nih.gov/ pubmed/21570780>. Acessed: nov 2, 2012.

NORMAN, K.N. et al. Prevalence and genotypic characteristics of Clostridium difficile in a closed and integrated human and swine population. Applied and Environmental Microbiology, v.77, n.16, p.5755-5760, 2011. Avaliable from: <http://www.ncbi.nlm.nih.gov/pubmed/21724899>. Acessed: nov $2,2012$.

OLDFIELD, E.C. Clostridium difficile-associated diarrhea: risk factors, diagnostic methods, and treatment. Reviews in Gastroenterological Disorders, v.4, n.4, p.186-195, 2004. 
Avaliable from: <http://www.ncbi.nlm.nih.gov/pubmed/ 15580153>. Acessed: nov 2, 2012.

POST, K.W. et al. Evaluation of a test for Clostridium difficile toxins A and B for the diagnosis of neonatal swine enteritis. Journal of Veterinary Diagnostic Investigation, v.14, n.3, p.258-259, 2002. Avaliable from: <http://www.ncbi.nlm.nih.gov/ pubmed/12033686>. Acessed: nov 2, 2012. doi: 10.1177/ 104063870201400314 .

PREIS, I.S. et al. Enteritis associated with Clostridium difficile and opportunistic candidiasis in a foal. Brazilian Journal of Veterinary Pathology, v.5, n.1, p.7-11, 2012.

RAMIREZ, N. et al. Kinetic evidence for the presence of putative germination receptors in Clostridium difficile spores. Journal of Bacteriology, v.192, n.16, p.4215-4222, 2010. Avaliable from: <http://www.ncbi.nlm.nih.gov/pubmed/ 20562307>. Acessed: nov 2, 2012. doi: 10.1128/?JB.00488-10.

RODRIGUEZ-PALACIOS, A. Natural and experimental infection of neonatal calves with Clostridium difficile. Veterinary Microbiology, v.124, n.2, p.166-172, 2007. Avaliable from: <http://www.ncbi.nlm.nih.gov/pubmed/ 17481830>. Acessed: nov 2, 2012. doi: 10.1016/ j.vetmic.2007.03.016.

RUPNIK, M. et al. Revised nomenclature of Clostridium difficile toxins and associated genes. Journal of Medical Microbiology, v.54, p.113-117, 2005. Avaliable from: <http:/ /www.ncbi.nlm.nih.gov/pubmed/15673503>. Acessed: nov 2, 2012. doi: 10.1099/jmm.0.45810-0.

SAMIE, A. et al. PCR detection of Clostridium difficile triose phosphate isomerase $(t p i)$, toxin A $(t c d A)$, toxin B $(t c d B)$, binary toxin $(c d t A, c d t B)$, and $t c d C$ genes in Vhembe District, South Africa. American Journal of Tropical Medicine and Hygiene. v.78, n.4, p.577-585, 2008. Avaliable from: <http:// www.ncbi.nlm.nih.gov/pubmed/18385352>. Acessed: nov 2, 2012.

SCHMIDT, M.L. et al. Clostridium difficile testing algorithms: what is practical and feasible? Anaerobe, v.6, p.270-273, 2009. Avaliable from: <http://www.ncbi.nlm.nih.gov/pubmed/ 19853666>. Acessed: nov 2, 2012. doi: 10.1016/ j.anaerobe.2009.10.005.

SCHWAN, C. et al. Clostridium difficile toxin CDT induces formation of microtubule-based protrusions and increases adherence of bacteria. PLos Pathogens, v.5, n.10, e1000626, 2009. Avaliable from: <http://www.ncbi.nlm.nih.gov/pubmed/ 19834554>. Acessed: nov 2, 2012.

SILVA, R.O.S. et al. Detection of toxins A/B and isolation of Clostridium difficile from piglets in Brazil. Ciência Rural, v.41 n.8 p.1130-1135, 2011.

SILVA, R.O.S. et al. Detection of toxins A/B and isolation of Clostridium difficile and Clostridium perfringens from dogs in Brazil. Brazilian Journal of Microbiology, 2013. In press.

SILVA, R.O.S. et al. First confirmed case of Clostridium difficileassociated diarrhea in foals in Brazil. Ciência Rural, v.42, n.3, p. 498-500, 2012.
SONGER, J.G. Clostridia as agents of zoonotic disease. Veterinary Microbiology, v.140, p.399-404, 2010. Avaliable from: <http://www.ncbi.nlm.nih.gov/pubmed/19402980>. Acessed: nov 2, 2012. doi: 10.1016/j.vetmic.2009.07.003.

SONGER, J.G. et al. Clostridium difficile in retail meat products, USA, 2007. Emerging Infectious Diseases, v.15, n.5, p.819821, 2009. Avaliable from: <http://wwwnc.cdc.gov/eid/article/ 15/5/08-1071.htm>. Acessed: nov 2, 2012.

SONGER, J.G. et al. Prevention of porcine Clostridium difficileassociated disease by competitive exclusion with nontoxigenic organisms. Veterinary Microbiology, v.124, n.3-4, p.358361, 2007. Avaliable from: <http://www.ncbi.nlm.nih.gov/ pubmed/17493774>. Acessed: nov 2, 2012. doi: 10.1016/ j.vetmic.2007.04.019.

SONGER, J.G. The emergence of Clostridium difficile as a pathogen of food animals. Animal Health Research Reviews, v.5, n.2, p.321-326, 2004. Avaliable from: <http://www.ncbi.nlm.nih.gov/ pubmed/15984348>. Acessed: nov 2, 2012.

SONGER, J.G.; UZAL, F.A. Clostridial enteric infections in pigs. Journal of Veterinary Diagnostic Investigation, v.17, n.6, p.528-536, 2005. Avaliable from: <http://www.ncbi.nlm.nih.gov/ pubmed/16475510>. Acessed: nov 2, 2012.

SONGER, J.G.; ANDERSON, M.A. Clostridium difficile: an important pathogen of food animals. Anaerobe, v.12, n.1, p.1-4, 2006. Avaliable from: <http://www.ncbi.nlm.nih.gov/ pubmed/16701605>. Acessed: nov 2, 2012. doi: 10.1016/ j.anaerobe.2005.09.001.

STRUBLE, A.L. et al. Fecal shedding of Clostridium difficile in dogs: a period prevalence survey in a veterinary medical teaching hospital. Journal of Veterinary Diagnostic Investigation, v.6, p.342-347, 1994. Avaliable from: <http://www.ncbi.nlm.nih.gov/ pubmed/7948204>. Acessed: nov 2, 2012.

UZAL F.A. et al. Clostridium perfringens type $\mathrm{C}$ and Clostridium difficile co-infection in foals. Veterinary Microbiology, v.156, n.4, p.395-402, 2012. Avaliable from: <http:// www.ncbi.nlm.nih.gov/pubmed/22177970>. Acessed: nov 2, 2012. doi: 10.1016/j.vetmic.2011.11.023.

WEESE, J.S. et al. Survival of Clostridium difficile and its toxins in equine feces: implications for diagnostic test selection and interpretation. Journal of Veterinary Diagnostic Investigation, v.12, n.4, p.332-336, 2000. Avaliable from: <http://www.ncbi.nlm.nih.gov/pubmed/10907862>. Acessed: nov $2,2012$.

YAEGER, M. J. et al. A prospective, case control study evaluating the association between Clostridium difficile toxins in the colon of neonatal swine and gross and microscopic lesions. Journal of Veterinary Diagnostic Investigation, v.19, n.1, p.52-59, 2007. Avaliable from: <http://www.ncbi.nlm.nih.gov/ pubmed/17459832>. Acessed: nov 2, 2012. 